\title{
The Effect of Mineral Supplementation on the Physiological Quality, Enzymes Activity and the Soybean Seedlings Development
}

\author{
Gerusa Massuquini Conceição (Corresponding author) \\ Northwestern Regional University of Rio Grande do Sul State, Ijuí, Brazil \\ Tel: +55 (55) - 3332-0200Ｅ-mail: gerusa.conceicao@ unijui.edu.br
}

Thomas Newton Martin

Federal University of Santa Maria, Santa Maria, Rio Grande do Sul, Brazil Tel: +55 (55) - 8111-3833Ｅ-mail: martin.ufsm@gmail.com

\section{Luciane Almeri Tabaldi}

Federal University of Santa Maria, Santa Maria, Rio Grande do Sul, Brazil Tel: +55 (55) - 9113-3989 E-mail: lutabaldi@yahoo.com.br

Glauber Monçon Fipke

Federal University of Pampa, Itaqui, Rio Grande do Sul, Brazil Tel: +55 (55) - 9163-4266 E-mail: glauber.unipampa@gmail.com

Charleston dos Santos Lima

Federal University of Santa Maria, Santa Maria, Rio Grande do Sul, Brazil Tel: +55 (55) 99138-8111Ｅ-mail: charlescep009@gmail.com

Received: March 16, 2020 doi:10.5296/jas.v8i4.16678
Accepted: Sep. 7, 2020

Published: Nov. 9, 2020

URL: https://doi.org/10.5296/jas.v8i4.16678 


\section{Abstract}

The quality of soybean seeds is influenced by the amount of nutrients that are available for the germination and initial development of the seedlings. Thus, the aim of this research was to evaluate the influence of the nutritional content of the seeds and mineral supplementation via seed treatment on physiological quality, enzymatic activity and initial development of soybean seedlings. We assessed soybean seeds from two lots with low and high nutritional content, submitted or not to mineral supplementation via seed treatment. The physiological quality of seeds was assessed by the germination test and first germination count. The initial development of seedlings was evaluated by the tests of length and root system volume, shoot length, and cotyledons, roots and shoot dry matter. It was also determined the activity of $\alpha$-amylase in cotyledons, acid phosphatase (APase) and guaiacol peroxidase (POD) in the roots and shoot. Mineral supplementation via seed treatment positively influenced the physiological quality and development of seedlings, and the activity of $\alpha$-amylase in the cotyledons, POD and APase enzymes in the shoot from the low nutrient lot. Low nutrient seeds have characteristics of soybean seedling production similar to those of high nutrient content by using mineral supplementation via seeds.

Keywords: seeds, nutritional content, enzymatic activity, physiological quality

\section{Introduction}

The performance of the soybean crop is highly influenced by the use of high quality seeds, which are capable of ensuring adequate plant stands in the field and reflecting higher yields. For this, the seed must have, besides genetic, physical and sanitary attributes, high physiological quality, that is, it must present high germination rates and strength (Scheeren et al., 2010). The level of physiological quality of the seeds depends on several factors, including the chemical composition, that is, the content of reserves (Seyyedi et al., 2015), since germination involves complex processes and their utilization is fundamental for the formation of new seedlings (Ishibashi et al., 2013). In general, seeds with low amounts of reserves are unable to produce strong seedlings due to low nutrient availability (Hojjat, 2011).

As the seeds produced have variability, one must understand the enzymatic and physiological features of each seeds lot, before to apply any product. Especially when mineral fertilization occurs through seed treatment. However, the supplementation of seeds is not well understood regarding the activity enzymatic, physiological and morphological effects in germination and emergency from seeds with different nutritional contents. The incorrectly use of nutrients via seed treatment can cause economic losses in seed lots. Which can cause a saline environment and a low $\mathrm{pH}$ in the sowing furrow, reducing and / or delaying seed germination. It is necessary to explain the processes of activity physiological, enzymatic and morphological repercussions in order to be possible application of mineral supplementation in seeds lots that present real needs.

Along with the chemical composition of the seeds, the activity of enzymatic systems related to the mobilization of reserves and the maintenance of cellular integrity influence the germination process. In addition to enzymes responsible for metabolic modifications and 
energy availability for embryo growth such as $\alpha$-amylase and acid phosphatase, several other genes directly related to respiration may be involved in controlling the physiological quality of seeds (Oliveira et al., 2013). Seeds of lower physiological quality present higher respiratory rates and may present oxidative stress due to the formation of reactive oxygen species (ROS) and free radicals (Apel \& Hirt, 2004). Thus, antioxidant enzymes such as peroxidase (POD) play a key role in defense and maintenance of cell membranes (Simova-Stoilova et al., 2008). The nutritional aspects of soybean seeds are determined by environmental conditions, among them the availability of water at different stages of crop development. Seed protein, palmitic and linoleic acids, sucrose, raffinose, stachyose, N, P, K, and $\mathrm{Ca}$ significantly decreased, while stearic, oleic and linolenic acids, $\mathrm{Fe}, \mathrm{Mg}, \mathrm{Zn}, \mathrm{Cu}$, and $\mathrm{B}$ increased in response to soil moisture deficiency (Wijewardana et al., 2019). Mertz-Henning et al. (2018), determined that protein content was higher while oil content was lower when soybean cultivars were subjected to water stress conditions in the reproductive stage. This is directly related to the absorption of mineral nutrients in the soil and the physiological capacity of seeds to form more protein or oil, mediated by water content. So water stress causes a reduction in chlorophyll content, relative leaf water content, increasing osmolyte content, antioxidant potential and membrane lipid peroxidation (Dong et al., 2019).

Therefore, there is a need to research new technologies that seek to increase the availability of nutrients for the initial development of seedlings as well as to act on the maintenance of the activity of the enzymatic systems allowing the fast and uniform establishment of the seedlings. In this context, mineral supplementation via seed treatment is a practical and low-cost method to promote the physiological aspects of the seeds produced (Shah et al., 2012). According to Bishnoi et al. (2007) and Sawan et al. (2011), evidence that nutrition affects seed strength is increasingly concrete. Thus, the goal of this research was to evaluate the influence of nutritional content and mineral supplementation via seed treatment on physiological quality and enzimatic in initial development of soybean seedlings.

\section{Material and Methods}

\subsection{Place of the experimental and Material}

The study was carried out in the seeds laboratory and vegetal physiology of university federal Santa Maria, Brazil.

Soybean seeds of the cultivar BMX Potência RR were obtained from lots of high and low nutritional content obtained in the 2013/14 harvest. The seed water content was to $12 \%$, and the mass of 1000 seeds showed average values of 148 and 153 grams to the low and high nutritional content lot, respectively. The chemical characterization of seed lots is presented in Table 1. 
Table 1. Characterization of soybean seed lots with low and high nutritional content

\begin{tabular}{ccccccc}
\hline Lot & First count & Germination & Nitrogen & Phosphorus & Potassium & Calcium \\
\hline & $--------------(\%)----------$ & $------------\left(\mathrm{g} \mathrm{kg}^{-1}\right)$------------- & -- $\left(\mathrm{g} \mathrm{mg}^{-1}\right)$-- \\
Low & 80 & 89 & 70.30 & 3.87 & 11.75 & 2.00 \\
High & 86 & 92 & 81.70 & 4.07 & 17.25 & 2.25 \\
\hline
\end{tabular}

\subsection{Treatments and Mineral Supplementation of Seeds}

Treatments were arranged in a factorial $2 \times 2$ (lots $\mathrm{x}$ seed treatment) for the variables germination and first germination count; a factorial $2 \times 2 \times 2$ (lots $\times$ treatment of seeds $\mathrm{x}$ moment of assessment) for dry matter and shoot length; a factorial $2 \times 2 \times 3$ (lots $\times$ seed treatment $\mathrm{x}$ moment of assessment) for dry matter, length and volume of the root system and dry matter of cotyledons; a factorial $2 \times 2 \times 4$ (lots $x$ seed treatment $\times$ moment of assessment) for the biochemical determinations of shoot, and a factorial $2 \times 2 \times 5$ (lots $\times$ seed treatment $\mathrm{x}$ moment of assessment) for the biochemical determinations of the roots and cotyledons. The experimental design was completely randomized with four replications. The seeds of the lots of low and high nutritional content were submitted to mineral supplementation. Seed treatment was carried out in plastic containers with capacity of three liters, using 500 grams of seeds per package, at the dose of $200 \mathrm{~mL} 100 \mathrm{~kg}-1$ of seed, with volume of syrup $600 \mathrm{~mL}$ $100 \mathrm{~kg}-1$ of seed, filled with distilled water. Posteriorly upon treatment, the plastic bags were opened, allowing the seeds to dry at room temperature environment for a period of 24 hours. Chemical composition of the mineral supplement: $48 \mathrm{~g} \mathrm{~L}^{-1}$ of $\mathrm{N}, 80 \mathrm{~g} \mathrm{~L}^{-1}$ of $\mathrm{P}_{2} \mathrm{O}_{5}, 16 \mathrm{~g} \mathrm{~L}^{-1}$ of $\mathrm{K}_{2} \mathrm{O}, 16 \mathrm{~g} \mathrm{~L}^{-1}$ of Ca, $8 \mathrm{~g} \mathrm{~L}^{-1}$ of $\mathrm{Mg}, 3.2 \mathrm{~g} \mathrm{~L}^{-1}$ of Co, $8 \mathrm{~g} \mathrm{~L}^{-1}$ of $\mathrm{Cu}, 32 \mathrm{~g} \mathrm{~L}^{-1}$ of Mn, $160 \mathrm{~g} \mathrm{~L}^{-1}$ of Mo, $1.6 \mathrm{~g} \mathrm{~L}^{-1}$ of Ni, and $16 \mathrm{~g} \mathrm{~L}^{-1}$ of $\mathrm{Zn}$.

\subsection{Assessment}

\subsubsection{Germination and Development of Soybean Seedlings}

Water content, one thousand seeds mass, first count of the germination test, and germination were measured according to the Seed Analysis Rules (Brasil, 2009). For the assessment of the length of seedlings, root volume and dry matter, 15 seeds were placed to germinate in biochemical oxygen demand [B.O.D.] equipment at $25^{\circ} \mathrm{C}$ using paper rolls moistened with distilled water as substrate. For initial growth assessment, 5 normal seedlings per replication were randomly collected at 2, 6 and 10 days after sowing. Soon after, the seedlings were separated into their root systems, shoot and cotyledons. Root system and shoot were packed in acrylic laminates and arranged in an EPSON Expression 11000 scanner, equipped with additional light (TPU), with a resolution of $600 \mathrm{dpi}$, using WinRhizo Pro 2013 software, which measured the length and volume of the root system, length of the shoot and root system. Subsequently, the root system, the shoot and cotyledons were oven dried with forced air at $65^{\circ} \mathrm{C}$ until constant dry matter. After the samples were removed from the greenhouse, they were placed in a desiccator for 15 minutes and weighed to determine the dry mass of the root system, shoot and cotyledons, and the results were expressed as mg seedling ${ }^{-1}$. 


\subsubsection{Biochemical Analyzes}

For the biochemical characterization, 30 seeds of each treatment were placed to germinate in a B.O.D. incubator at $25^{\circ} \mathrm{C}$, using paper rolls moistened with distilled water as substrate. Twenty seedlings were randomly collected at 2, 4, 6, 8 and 10 days after sowing. Soon after, they were separated into root system, shoot and cotyledons, then the activity of the acid phosphatase and guaiacol peroxidase enzymes in the root system were determined. In addition, the amount of total chlorophyll and carotenoids in the shoot and the activity of the $\alpha$-amylase enzyme in the cotyledons were determined as described below.

$\alpha$-Amylase Enzyme: $0.5 \mathrm{~g}$ of plant tissue was used. After being treated with acetic acid, the plant tissue was macerated in a mortar with $20 \mathrm{~mL}$ of potassium acetate buffer $(\mathrm{pH} 7.0)$, and the mixture was centrifuged at 3,000 rpm for 15 minutes. The supernatant was removed and placed in test tubes kept under refrigeration at $4^{\circ} \mathrm{C}$ for carrying out the analyses. For the determination of $\alpha$-amylase activity, the extract obtained was placed in a water bath at $70^{\circ} \mathrm{C}$ for 20 minutes. Four $0.1 \mathrm{~mL}$ aliquots were withdrawn and placed in test tubes along with 1 $\mathrm{mL}$ of potassium acetate buffer and $1 \mathrm{~mL}$ of starch solution, and incubated for five minutes at $30^{\circ} \mathrm{C}$. After that, $1 \mathrm{~mL}$ of lugol solution and $9 \mathrm{~mL}$ of distilled water were added. The readings were performed in spectrophotometer E - 225D at $620 \mathrm{~nm}$ (AOSA, 1983). Data from the readings were transformed according to the formula described by Ching (1973).

Enzyme guaiacol peroxidase (POD): A plant tissue sample $(0.5 \mathrm{~g})$ was homogenized in $3 \mathrm{~mL}$ of $0.05 \mathrm{M}$ sodium phosphate buffer ( $\mathrm{pH} 7.8)$ containing $1 \mathrm{mM}$ of EDTA and $2 \%(\mathrm{w} / \mathrm{v})$ of polyvinylpyrrolidone (PVP). The homogenate was centrifuged at 13,000 x $g$ for 20 minutes at $4^{\circ} \mathrm{C}$ and the supernatant was used for POD determination. POD activity was determined by the absorbance of the reaction solution at $470 \mathrm{~nm}$, according to Zeraik et al. (2008).

Acid Phosphatase Enzyme (APase): $0.5 \mathrm{~g}$ of plant tissue sample was macerated in liquid $\mathrm{N}_{2}$ and homogenized in $100 \mathrm{mM}$ of Tris- $\mathrm{HCl}$ buffer $(\mathrm{pH} 7.4), 1.0 \mathrm{mM}$ of ethylenediaminetetraacetic acid (EDTA), and $0.1 \%$ of albumin at a $1: 3$ ratio $(\mathrm{m} / \mathrm{v})$, then centrifuged at $20,000 \mathrm{~g}$ for 30 minutes at $4^{\circ} \mathrm{C}$, and the resulting supernatant was used for enzyme assay. The activity of the acid phosphatases was determined according to Tabaldi et al. (2007). The inorganic phosphate (Pi), a product of the enzyme reaction, was quantified at $630 \mathrm{~nm}$ in a spectrophotometer model SF325NM (Bel Engineering, Italy) using malachite green as colorimetric reagent, and $\mathrm{KH}_{2} \mathrm{PO}_{4}$ as the standard for the calibration curve. The concentration of total proteins was quantified by Bradford's method (1976).

Determination of chlorophyll and carotenoids: The pigments were extracted according to Hiscox \& Israeslstam's method (1979) and estimated by using Lichtenthaler's formula (1987). Fresh leaves $(0.05 \mathrm{~g})$ were incubated in a water bath at $65^{\circ} \mathrm{C}$ with dimethylsulfoxide (DMSO) until the complete extraction of pigments from the tissues (completely whitish tissues). The absorbance of the solution was measured at 663 and $645 \mathrm{~nm}$ for chlorophylls $a$ and $b$, respectively, and at $470 \mathrm{~nm}$ for carotenoids, in a spectrophotometer. The pigment concentration was expressed in $\mathrm{mg}^{-1}$ fresh mass. 


\subsection{Statistical Analysis}

In the statistical analysis of data in the variables with significance by F-test (ANOVA), the means were compared through the Scott-Knott test at a 5\% probability of error. For data analyses was utilized software SISVAR (Ferreira, 2014).

\section{Results and Discussion}

For the germination variable, no significant difference was found between mineral supplementation and the lots evaluated, with a mean value of $91.5 \%$ (data not shown). The lot of high nutritional content showed higher percentage of normal seedlings in the first count of the germination test than the lot of low nutritional content, regardless of the application or not of mineral supplementation (Table 2). The higher nutritional concentration present on the lot with high nutritional content provide a higher germination capacity, ensuring highest rate of normal seedlings (Siadat et al., 2012).

Table 2. First count of the germination test (Pc) of the cultivar BMX Potência RR with low and high nutrient content submitted or not to mineral supplementation by the seed treatment

\begin{tabular}{cccc}
\hline & \multicolumn{2}{c}{ Lots } \\
\cline { 2 - 3 } Seed treatment & Low nutrient & High nutrient & Average \\
\hline Without seed treatment & $71^{\mathrm{bB} *}$ & $83^{\mathrm{aA}}$ & 77 \\
With seed treatment & $80^{\mathrm{aB}}$ & $86^{\mathrm{aA}}$ & 82 \\
Average & 75 & 84 & \\
\hline
\end{tabular}

*Means followed by the same lowercase letters on the column, and uppercase letters in the row do not differ by the Scott-Knott test $(\mathrm{p}<0.05)$.

These results corroborate Pereira et al. (2015), who concluded that more vigorous soybeans showed a greater reserve content, and consequently, greater mobilization capacity, resulting in seedlings with better initial performance.

The first count of the germination test in the lot of high nutritional content was not influenced by mineral supplementation (Table 2). Differently, in the lot of low nutritional content, there was an increase of $12 \%$ in the first count with mineral supplementation. This result is probably due to the fact that, in this lot, there might have been a higher absorption of the nutrients applied. These findings showed that a nutritional limitation may stimulate the expression of high affinity transporter genes, facilitating the transport of nutrients through the membrane, thus favoring their absorption.

Zhao et al. (2018) point out that the initial germination period is not exclusively related to the reserve content, but also related to their degradation at the essential moments for the mobilization and growth of the embryonic axis. Then the enzymes responsible for breaking down reserve substances like $\alpha$-amylase, peptides and proteases need to be activated. Ochiai et al. (2014) constructed the crystallized structure of $\alpha$-amylase, which highlights that in the 
composition of the enzyme, besides essential amino acids and phytormones, calcium ions $\left(\mathrm{Ca}^{+2}\right)$ are extremely important to maintain its stabilization. This consolidate the function of mineral supplementation, supplying the nutrient demand in the lower nutritional quality lot, for the activation of enzymes responsible for making soluble sugars and proteins available to the embryo, justifying the results for the lower nutritional lot with supplementation. Conceição et al. (2018), when submitting lots of low and high nutritional soybean seeds to treatment with mineral supplementation, found that higher nitrogen absorption from the fertilizer occurred in lower nutritional quality lots, which may be linked to the high affinity of soybean transporters membrane, leading the element to the cellular cytoplasm, interacting in the construction of compounds.

In the absence of mineral supplementation, the production of higher dry matter of cotyledons (Table 3) occurred in the lots of high nutritional content. However, when submitted to nutrients addition, there was no difference in the amount of dry matter between the lots. Conceição et al. (2018) found that when evaluating the absorption of $\mathrm{N}$ derived from mineral supplementation in soybean seed germination that, lower nutritional quality lots tend to absorb a higher percentage of N. In addition, in the germination process energy is released and conserved in the form of ATP, using carbohydrate substrates such as starch, sucrose, fructose, glucose, lipids, and proteins (De Oliveira et al., 2015), with significant loss of dry matter, which occurs more prominently in lots of lower strength, in response to lower reserve content.

In seeds with lower physiological quality, besides having lower reserves content, their translocation to different parts of the plant is limited. This occurs in response to the slower seed hydration pattern, a process related to longer membrane repair time in the process hydration, before embryonic axis growth begins, which may result in less dry matter in different parts of the plant (Ehrhardt-Brocardo et al., 2016).

Table 3. Dry matter of cotyledons (DMC), shoot length (SL), and dry matter of shoot (DMS); and root system length (RSL), root system volume (RSV), and dry matter of the root system (DMR) of soybean seedlings derived from seeds of cultivar BMX Potência RR with low and high nutritional content submitted or not to mineral supplementation

\begin{tabular}{cccc}
\hline & \multicolumn{2}{c}{ Lots } & \\
\cline { 2 - 3 } Seed treatment & Low nutrient & Average \\
\hline & \multicolumn{2}{c}{ Cotyledons } \\
\hline Without ST & $436.08^{\mathrm{bB}}$ & $465.87^{\mathrm{aA}}$ & \\
With ST & $469.52^{\mathrm{aA}}$ & $474.54^{\mathrm{aA}}$ & 472.03 \\
Average & 452.80 & 470.20 & 450.97 \\
\hline
\end{tabular}

Shoot

$\mathrm{SL}(\mathrm{cm})$ 
Without ST

With ST

Average
$12.30^{\mathrm{bB}}$

$15.48^{\mathrm{aA}}$

13.89
13.46

15.33

$15.18 \mathrm{aA}$

14.90

DMS (mg)

Without ST

$79,41^{\mathrm{bB}}$

$107,81^{\mathrm{aA}}$

93,61

With ST

$99,01^{\text {aA }}$

$108^{\text {aA }}$

104,77

Average

90,18

108,20

Root

\begin{tabular}{|c|c|c|c|}
\hline \multicolumn{4}{|c|}{ Root } \\
\hline Without ST & $30,22^{\mathrm{bB}}$ & $42,74^{\mathrm{aA}}$ & 36,48 \\
\hline With ST & $45,32^{\mathrm{aA}}$ & $42,45^{\mathrm{aA}}$ & 43,88 \\
\hline Average & 36,33 & 44,03 & \\
\hline Without ST & $27,73^{\mathrm{bB}}$ & $52^{\mathrm{aA}}$ & 40,16 \\
\hline With ST & $40,37^{\mathrm{aB}}$ & $55^{\mathrm{aA}}$ & 48,07 \\
\hline Average & 34,05 & 54,17 & \\
\hline
\end{tabular}

Days after sowing

\begin{tabular}{|c|c|c|c|}
\hline 2 & $1.97^{\mathrm{cA}}$ & $2.29^{\mathrm{cA}}$ & 2.13 \\
\hline 6 & $44.71^{\mathrm{bB}}$ & $54.91^{\mathrm{bA}}$ & 49.81 \\
\hline 10 & $62.33^{\mathrm{aB}}$ & $74.89^{\mathrm{aA}}$ & 68.61 \\
\hline Average & 36.33 & 44.03 & \\
\hline 2 & $0.04^{\mathrm{cA}}$ & $0.04^{\mathrm{cA}}$ & 0.04 \\
\hline 6 & $0.13^{\mathrm{bB}}$ & $0.18^{\mathrm{bA}}$ & 0.15 \\
\hline 10 & $0.18^{\mathrm{aA}}$ & $0.20^{\mathrm{aA}}$ & 0.19 \\
\hline Average & 0.11 & 0.14 & \\
\hline 2 & $22.85^{\mathrm{cA}}$ & $23.78^{\mathrm{cA}}$ & 23.31 \\
\hline 6 & $35.90^{\mathrm{bB}}$ & $52.81^{\mathrm{bA}}$ & 44.35 \\
\hline 10 & $43.41^{\mathrm{aB}}$ & $65.93^{\mathrm{aA}}$ & 59.67 \\
\hline Average & 34.05 & 54.17 & \\
\hline
\end{tabular}


*Means followed by the same lowercase letters in the column, and uppercase letters in the row do not differ by the Scott-Knott test $(\mathrm{p}<0.05)$.

For the SL, DMS, RSL, and DMR variables, there was similar behavior for such parameters in the absence and presence of mineral supplementation, except DMR (Table 3). For these variables, the highest results without supplementation occurred in lots of high nutritional content, which evidences the influence of seeds with superior nutritional and physiological quality on seedling generation with higher dry matter of shoot, root, stem diameter, number of nodules and nodule mass. In addition to increasing germination percentages and emergence velocity (Caverzan et al., 2018). However, when the seeds were submitted to supplementation, there was no significant difference between the lots, which represents the contribution of nutrient application to the seeds to meet their demand in physiological processes linked to degradation and reserve mobilization. Pacheco et al. (2012) informs out that bean plants originated from seeds enriched with $\mathrm{P}$ and Mo showed higher nodule mass and grain productivity.

According to the results for RSL, RSV, and DMR (Table 3), as well as LAP and DMAP (Table 4), there was an increase during the moments of assessment (2, 6 and 10 days after sowing), which was accompanied by a decrease in the dry matter of cotyledons (Table 4). The decrease in DMC is linked to the germination period, which depending on the species may be more pronounced in the first 24 hours, in response to the mobilization of reserves, resulting in the reduction of starch, protein and oil content, with respective increase in soluble sugars, free amino acids and fatty acids for construction of the photosynthetic apparatus (Erbas et al., 2016). These results are in agreement with Goyoaga et al. (2011), who analyzed the nutritional value and availability of nutrients in seeds and bean seedlings, which concluded that a decrease in the dry matter of cotyledons is accompanied by improvements in the root system and shoot.

Table 4. Isolated effect of assessment period in the dry matter of shoot (DMS), length of shoot (LS), dry matter of cotyledons (DMC), and effect of lots for root system volume (RSV) of soybeans seedlings derived from seeds of the cultivar BMX Potência RR of low and high nutritional content submitted or not to mineral supplementation

\begin{tabular}{cccccc}
\hline & Shoot & & Cotyledons & \multicolumn{2}{c}{ Root } \\
\hline Characters & DMS $(\mathrm{mg})$ & LS $(\mathrm{cm})$ & DMC $(\mathrm{mg})$ & \multicolumn{2}{c}{ RSV $\left(\mathrm{cm}^{3}\right)$} \\
\hline 2 & - & - & $611.00^{\mathrm{a}}$ & Lot & Average \\
6 & $72.24^{\mathrm{b}}$ & $9.83^{\mathrm{b}}$ & $445.90^{\mathrm{b}}$ & Low & $0.11^{\mathrm{b}}$ \\
10 & $136.14^{\mathrm{a}}$ & $18.96^{\mathrm{a}}$ & $327.61^{\mathrm{c}}$ & High & $0.14^{\mathrm{a}}$ \\
\hline
\end{tabular}

*Means followed by the same letter in the column do not differ with by the Scott-Knott test $(\mathrm{p}<0.05)$.

The activity of the $\alpha$-amylase enzyme in cotyledons of seedlings, in the absence of mineral supplementation, was higher for the lot of high nutritional content (Table 5). This is because this lot, in addition to having a greater amount of stored nutrients, probably has higher 
carbohydrate contents that, once hydrolyzed, have as main product the glucose that will be used for respiration and growth of the embryonic axis (Franco et al., 2002). Furthermore, enzymes such as lipases, phosphatases and amylases have reduced activity due to reduction in physiological quality (Hennig et al., 2010), as observed in the lot of low nutritional content without the addition of nutrients.

Table 5. Activity of the $\alpha$-amylase enzyme of the cultivar BMX Potência for lots of low and high nutritional content, submitted or not to mineral supplementation via seed treatment

\begin{tabular}{|c|c|c|c|}
\hline \multirow[b]{2}{*}{ Seed treatment } & \multicolumn{2}{|c|}{ Lots } & \multirow[b]{2}{*}{ Average } \\
\hline & Low nutrient & High nutrient & \\
\hline \multicolumn{4}{|c|}{----------- $\alpha$-amylase (mg of hydrolyzed starch $\min ^{-1} \mathrm{~g}^{-1}$ fresh matter)----------- } \\
\hline Without ST & $12338.10^{\mathrm{bB}}$ & $20699.13^{\mathrm{aA}}$ & 16518.56 \\
\hline With ST & $18795.60^{\mathrm{aA}}$ & $19547.99^{\mathrm{aA}}$ & 19171.30 \\
\hline Average & 15566.80 & 20123.51 & \\
\hline
\end{tabular}

*Means followed by the same lowercase letters in the column, and uppercase letters in the row do not differ by the Scott-Knott test $(\mathrm{p}<0.05)$.

An increase in $\alpha$-amylase enzyme activity occurred when seeds of low nutritional content were submitted to mineral supplementation (Table 5). This may have happened because the catalytic enzymes activity is controlled by cofactors such as metallic ions $\left(\mathrm{Mg}^{2+}\right.$ and $\left.\mathrm{Ca}^{2+}\right)$, which act on their activation (Pimentel et al., 2012). This same trend can be observed in Figure 1, which analyzes the behavior of the $\alpha$-amylase enzyme activity at 2, 4, 6, 8, and 10 days after sowing. Regardless of the seed lot in the presence of mineral supplementation, which contains metal ions in its formulation, the activity of the enzyme was optimized. As a calcium metalloenzyme (Pujadas \& Palau, 2001), probably the $\alpha$-amylase was activated by metals present in mineral supplementation, mainly calcium. A greater activity of the enzyme was observed two days after sowing, and over period evaluated, there was a reduction of the activity of the enzyme. Probably due to a decrease of carbohydrate contents in the reserves of the cotyledons, corroborating the results found by Oliveira et al. (2013) that observed higher activity of the $\alpha$-amylase enzyme after imbibition of corn seeds. 


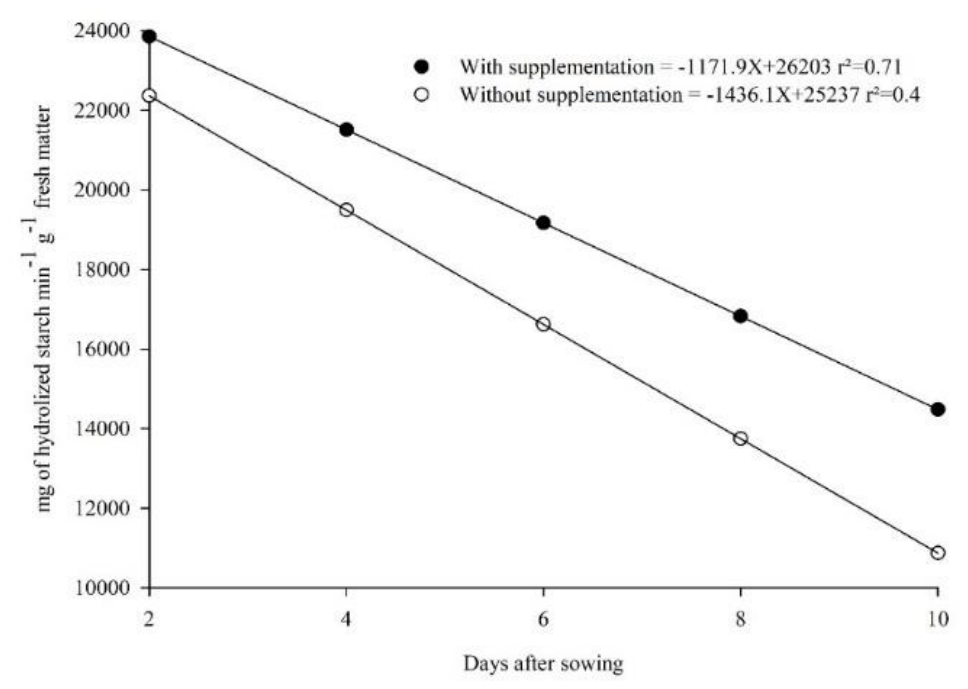

Figure 1. Activity of the $\alpha$-amylase enzyme in cotyledons of soybean seedlings of cultivar BMX Potência RR with and without mineral supplementation via seed treatment assessed at 2, 4, 6, 8 and 10 days after sowing

The activity of the POD enzyme during the assessment period increased in the root system, regardless of the lot and treatment of seeds with mineral supplementation (Figure 2), accompanied by an increase in RSL, RSV and DMR (Table 5 and Table 6). This higher activity in the post-germination stage indicates the possible involvement of POD in cell wall lignification as required in differentiating cells (Cosio \& Dunand, 2009). Besides, these results indicate also that the increase in POD activity was important for the efficient removal of hydrogen peroxide $\left(\mathrm{H}_{2} \mathrm{O}_{2}\right)$, one of the reactive oxygen species (ROS), avoiding damage to the membrane's lipids, proteins and DNA (Mittler, 2002). Contributing to the growth of seedlings by making them less susceptible to the deleterious action of ROS (Carvalho et al., 2014). Similar behavior occurred in the activities of POD, LAP and DMAP in the shoot of the seedlings throughout assessment moments (Figure 3).

Comparing the lots, POD activity in the shoot (Figure 3) at the end of assessment moments, was lower in the low nutrient lot without mineral supplementation, corroborating the data of LAP and DMAP for this lot, which presented lower performance. This indicates that these seeds presented lower antioxidant capacity because the maintenance of the isoenzyme activity of the antioxidant systems such as POD is important for seedlings growth, since they act in the removal and reduction of ROS that can cause cell damage (Deuner et al., 2011), and consequently, affect the quality of the seeds. However, this same behavior was not observed when the seeds of low nutritional content were submitted to the addition of nutrients in which the activity of the enzyme and initial growth of the seedlings was similar to the lot of high nutritional content with mineral supplementation until 10 days after sowing. Probably because a greater availability of nutrients favors enzyme activity, directly or indirectly.

APase activity in the root system decreased over the assessment periods (Figure 2). This is because this enzyme catalyzes the hydrolysis of a wide variety of phosphate monoesters, releasing inorganic phosphate $(\mathrm{Pi})$ from phosphorylated substrates that throughout 
germination and development of seedlings are used for growth (Branscheid et al., 2010). A further reduction of enzymatic activity was observed in the low nutrient lot without mineral supplementation. In this lot, this reduction of the enzyme activity possibly happened more quickly due to the lower amount of phosphorus in the reserves (Table 1). Thus, less energy for the maintenance of plant metabolism and initial growth was made available, as also observed in the first count of the germination test and initial seedling growth (Tables 2 and 4). Besides, probably, the lower availability of metal ions in the seeds of the low nutritional lot promoted a reduction in APase activity, since it is a metalloenzyme dependent on $\mathrm{Ca}^{2+}$ or $\mathrm{Mg}^{2+}$ (Tabaldi et al., 2011). In the mineral supplementation lots, this reduction in activity may be related to the gradual release of phosphorus (P) from the supplementation, which makes $\mathrm{P}$ available in a form readily assimilable by the plant (inorganic form). On the other hand, in the lots without mineral supplementation, $\mathrm{P}$ deficiency should promote an increase in the enzymatic activity, which did not occur in this study. Thus, we may suggest that some seed factor is impeding this APase activation in roots.
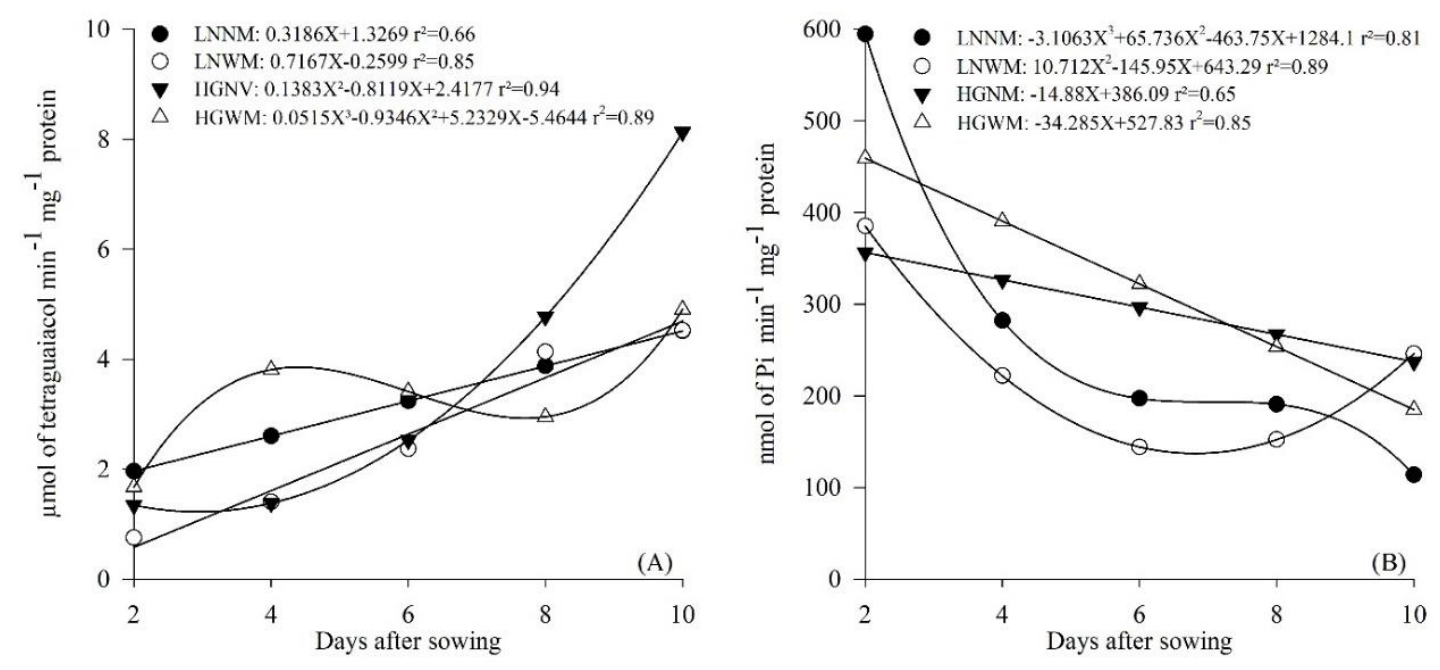

Figure 2. Activity of the enzymes guaiacol peroxidase (POD) (A) and acid phosphatase (APase) (B) in the root system of soybeans of the cultivar BMX Potência RR submitted or not to mineral supplementation assessed at 2, 4, 6, 8 and 10 days after sowing. Treatments: root system of seedlings originated from seeds of Low Nutritional content and No Mineral supplementation (LNNM); root system of seedlings originated from seeds of Low Nutritional Content with Mineral supplementation (LNWM); root system of seedlings originated from seeds of High Nutritional content and No Mineral supplementation (HGNM); root system of seedlings originated from seeds of High Nutritional Content with Mineral supplementation

(HGWM)

APase activity in the shoot in high and low nutrient lots without mineral supplementation increased in the first days after sowing (Figure 3), and the highest activity was observed in the high nutrient lot without supplementation. This result may be directly related to the lower APase activity in the root system, which provided less inorganic $\mathrm{P}$ to be transported to the shoot, promoting an enzyme activation in the shoot. This same behavior was not observed in the lot of high nutrient content with supplementation, possibly due to the greater availability 
of inorganic $\mathrm{P}$ in these seeds. However, for the lot of low nutritional content, the enzyme APase behaved inversely, since the greater activity of the enzyme occurred in the presence of mineral supplementation.

It still was observed that in the presence of mineral supplementation, which provides $\mathrm{P}$ in inorganic form, readily assimilable by the plant, there was an increase in APase activity in the shoot during the days after sowing. These results may be due to the fact that the Provided by the supplementation was initially used by the embryo/seedling for development and, later, the demand for $\mathrm{P}$ is supplied only by the seed reserves.

The contents of total $\mathrm{Chl}$ and carotenoids, regardless of the lot and seed treatment, increased 8 days after sowing and decreased at 10 days after sowing (Figure 3). This increase until eight days after sowing may have happened due to the occurrence of nutrient utilization of the seed reserves for the biosynthesis of these pigments, which were exhausted after this period, indicating that the seedling is not using the nutrients provided by mineral supplementation for pigment biosynthesis, as emphasized by Jiang et al. (2009).
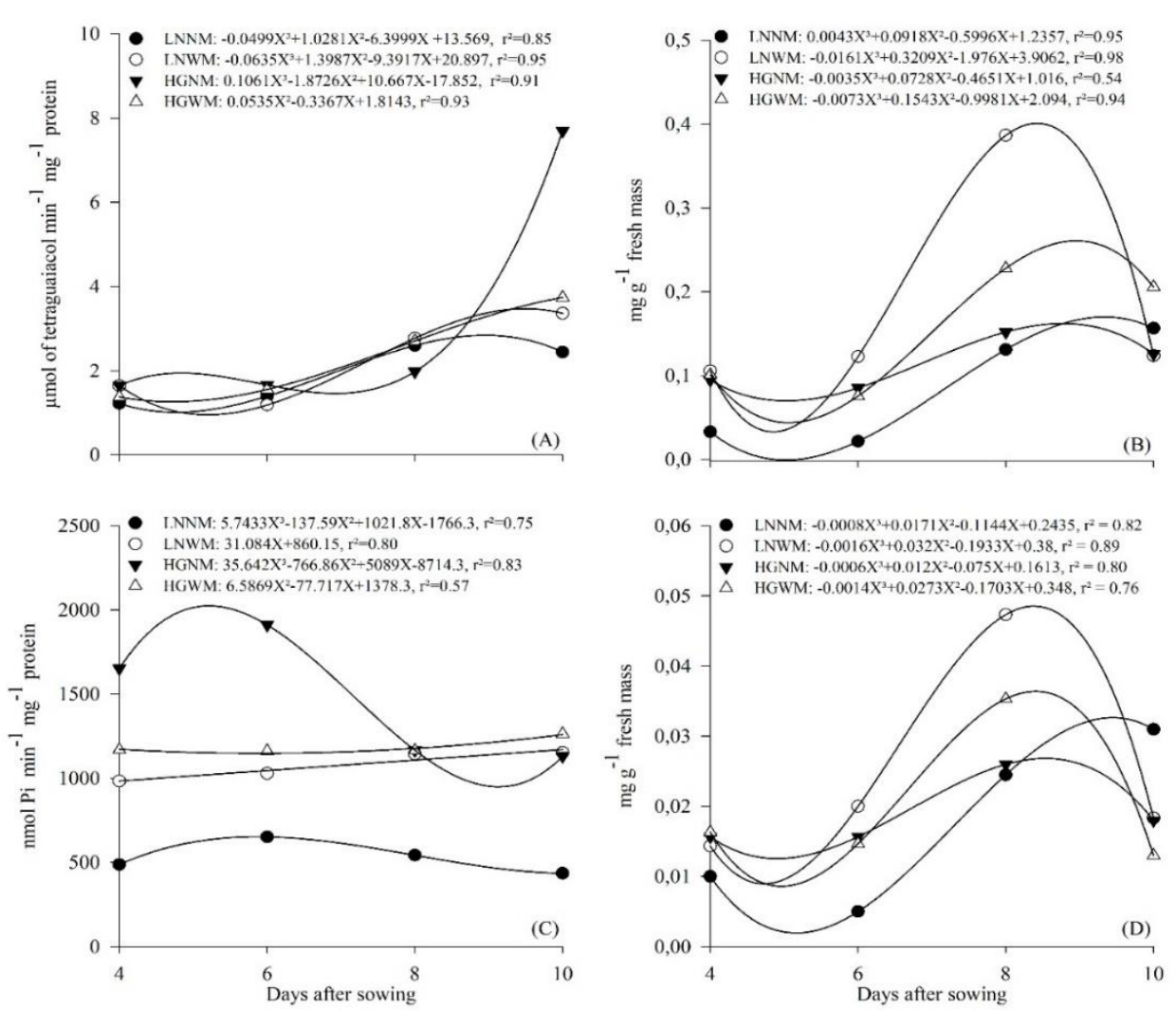

Figure 3. Activity of the enzymes guaiacol peroxidase (POD) (A), acid phosphatase (APase)

(C), total chlorophyll content (Chl Total) (B) and carotenoids (Carot) (D) in the shoot of soybean seedlings of cultivar BMX Potência RR submitted or not to mineral supplementation assessed at 4, 6, 8 and 10 days after sowing. Treatments: root system of seedlings originated

from seeds of Low Nutritional content and No Mineral supplementation (LNNM); root

system of seedlings originated from seeds of Low Nutritional content With Mineral supplementation (LNWM); root system of seedlings originated from seeds of High 


\section{$\triangle$ Macrothink}

Nutritional content and No Mineral supplementation (HGNM); root system of seedlings originated from seeds of High Nutritional content With Mineral supplementation (HGWM).

Jiang et al. (2009) still stated that changes in the amount of pigments may be indicative of some damage that may be occurring in the photosynthetic apparatus due to some biotic or abiotic stress, such as nutrient deficiency. The highest production of total $\mathrm{Chl}$ and carotenoids occurred in the low nutrient lot with mineral supplementation. These results corroborate those found in this study for the first count of germination and initial development of seedlings, in which this lot presented greater response to the addition of nutrients, indicating their greater absorption.

\section{Conclusion}

1. Seeds with higher stored reserves present better performance in relation to the physiological quality and initial development of seedlings.

2. Mineral supplementation via seed treatment has positive effects on the physiological quality and development of seedlings to the lot with low nutrient.

3. Mineral supplementation increases the $\alpha$-amylase enzyme activity of cotyledons, POD and APase in the aerial part of seedlings from the seeds with low nutritional content.

4. Low nutrient seeds have characteristics of soybean seedling production similar to those of high nutrient content by using mineral supplementation via seed.

\section{References}

[AOSA]. Association of Official Seed Analystis. Seed vigor testing handbook. (1983). Contrib. n.32 to the Handbook on seed testing. - (Ed.).

[BRASIL]. (2009). Rules for seed analysis. Ministry of Agriculture, Livestock and Supply. Secretariat for Agricultural Defense. Brasília, DF: Map/ACS, 395 p.

Apel, K., \& Hirt, H. (2004). Reactive oxygen species: metabolism, oxidative stress, and signal transduction. Annual Review of Plant Biology, 55, 373-399. https://doi.org/10.1146/annurev.arplant.55.031903.14

Bishnoi, U. R., Kaur, G., \& Khan, M. H. (2007). Calcium, phosphorus, and harvest stages effects soybean seed production and quality. Journal of Plant Nutrition, 30, 2119-2127. https://doi.org/10.1080/01904160701700608

Bradford, M. M. (1976). A rapid and sensitive method for the quantitation of microgram quantities of protein utilizing the principle of protein - dye binding. Plant Physiology Biochemistry, 72, 248-254. https://doi.org/10.1016/0003-2697(76)90527-3

Branscheid, A. (2010). Expression pattern suggests a role of MiR399 in the regulation of the cellular response to local $\mathrm{Pi}$ increase during arbuscular mycorrhizal symbiosis. Molecular Plant Microbe Interactions, 23, 915-926. https://doi.org/10.1094/mpmi-23-7-0915

Carvalho, E. R., Mavaieie, D. P. R., Oliveira, J. A., Carvalho, M. V., \& Vieira, A. R. (2014). 
Isozyme alterations in soybean cultivar seeds at different storage conditions. Pesquisa Agropecuária Brasileira, 49, 967-976. http://dx.doi.org/10.1590/S0100-204X2014001200007

Caverzan, A., Giacomin, R., Muller, M., Biazus, C., Lângaro, N.C., \& Chavarria, G. (2018). How does seed vigor affect soybean yield components. Crop Ecology and Physiology, 110, 1318-1327. https://doi.org/10.2134/agronj2017.11.0670

Ching, T. M. (1973). Biochemical aspects of seed vigour. Seed Science and Technology, 1, 73-88.

Conceição, G. M., Martin, T. N., Brunetto, G., Backes, R. L., DE Andrade, F. F., \& Beche, M. (2018). Contribution of nitrogen derived from mineral supplementation for soybean seedlings. Ciência e Agrotecnologia, 42, 33-41. https://doi.org/10.1590/1413-70542018421010617

Cosio, C., \& Dunand, C. (2009). Specific functions of individual class III POX genes. Journal of Experimental Botany, 60, 391-408. https://doi.org/10.1093/jxb/ern318

De Oliveira, L. M., Cavalheiro, V. B. D., De Moraes, D. M., Tilmann, M. A. A., \& Schuch, L. O. B. (2015). CO2 measurement as an alternative method to differentiate the vigor of watermelon seed lots. Rural Science, 45, 606-611. http://dx.doi.org/10.1590/0103-8478cr20130594

Deuner, C., Maia, M. de S., Deuner, S., Almeida, A. da S., \& Meneghello, G. E. (2011). Viability and antioxidant activity in seeds of cowpea genotypes submitted to salt stress. $\begin{array}{lllll}\text { Revista Brasileira de } & \text { 711-720. }\end{array}$ http://dx.doi.org/10.1590/S0101-31222011000400013

Dong, S., Jiang, Y., Dong, Y., Wang, L., Wang, W., Ma, Z., \& Liu, L. (2019). A study on soybean responses to drought stress and rehydration. Saudi Journal of Biological Sciences. Article in press, https://doi.org/10.1016/j.sjbs.2019.08.005

Ehrhardt-Brocardo, N. C. M., \& Coelho, C. M. M. (2016). Hydration patterns and physiologic quality of common bean seeds. Semina: Ciências Agrárias, 37, 1791-1800. http://dx.doi.org/10.5433/1679-0359.2016v37n4p1791

Erbas, S., Tonguç, M., Karakurt, Y., \& Sanli, A. (2016). Mobilization of seed reserves during germination and early seedling growth of two sunflower cultivars. Journal of Applied Botany and Food Quality, 89, 217-222. https://doi.org/10.5073/JABFQ.2016.089.028

Ferreira, D. F. (2014). Sisvar: a Guide for its Bootstrap procedures in multiple comparisons. Ciência e agrotecnologia, 38, 109-112.

Franco, O. L., Rigden, D. J., Melo, F. R., \& Grossi, M. F. (2002). Plant a-amylase inhibitors and their interaction with insect a-amylases. Europen Journal Biochemistry, 269, 397-412. https://doi.org/10.1046/j.0014-2956.2001.02656.x

Goyoaga, C., Burbano, C., Cuadrado, C., Romero, C., Guillamon, E., Varela, A., Pedrosa, M. M., \& Muzquiz, M. (2011). Content and distribution of protein, sugars and inositol phosphates during the germination and seedling growth of two cultivars of Vicia faba. 
Journal of Food Composition and Analysis, 24, 391-397. https://doi.org/10.1016/j.jfca.2010.11.002

Hennig, F. A., Mertz, L. M., Junior, E. A. J., Machado, R. D., Fiss, G., \& Zimmer, P. D. (2010). Composição química e mobilização de reservas em sementes de soja de alto e baixo vigor. Bragantia, 69, 727-734. https://doi.org/10.5935/PAeT.V8.N3.01

Hiscox, J. D., \& Israelstam, G. F. (1979). Method for the extraction of chlorophyll from leaf tissue without maceration. Canadian Journal of Botany-Revue Canadienne De Botanique, 57, 1332-1334.

Hojjat, S. S. (2011). Effects of seed size on germination and seedling growth of some lentil genotypes (Lens culinaris Medic.). International Journal Agriculture Crop Science, 3, 1-5. https://doi.org/10.9790/2380-08328387

Ishibashi, Y., Koda, Y., Zheng, S. H., Yuasa, T., \& Iwaya-inoue, M. (2013). Regulation of soybean seed germination through ethylene production in response to reactive oxygen species. Annals of Botany, 1, 1-8. https://doi.org/10.1093/aob/mcs240

Jiang, H. X., Tang, N., \& Zheng, J. G. (2009). Phosphorus alleviates aluminum- induced inhibition of growth and photosynthesis in Citrus grandis seedlings. Physioly Plantarum, 137, 298-311. https://doi.org/10.1111/j.1399-3054.2009.01288.x

Lichtenthaler, H. K. (1987). Chlorophylls and Carotenoids - pigments of photosynthetic biomembranes. Methods in Enzymology, 148, 350-382. https://doi.org/10.1016/0076-6879(87)48036-1

Mertz-Henning, L., Ferreira, L., Henning, F., Mandarino, J., Santos, E., Oliveira, M., \& Neumaier, N. (2018). Effect of water deficit-induced at vegetative and reproductive stages on protein and oil content in soybean grains. Agronomy, 8, 3. https://doi.org/10.3390/agronomy8010003

Mittler, R. (2002). Oxidative stress, antioxidants and stress tolerance. Trends in Plant Science, 7, 405-410. https://doi.org/10.1016/s1360-1385(02)02312-9

Ochiai, A., Sugai, H., Harada, K., Tanaka, S., Ishiyama, Y., Ito, K., Tanaka, T., Uchiumi, T., Taniguchi, M., \& Mitsui, T. (2014). Crystal structure of $\alpha$-amylase from Oryza sativa: molecular insights into enzyme activity and thermostability. Bioscience, Biotechnology, and Biochemistry, 78, 989-997. https://doi.org/10.1080/09168451.2014.917261

Oliveira, G. E., Von pinho, R. G., Andrade, T. A., Von pinho, E. V. R., Santos, D., \& Delly Veiga, A. (2013). Physiological quality and amylase enzyme expression in maize seeds. Ciência e Agrotecnologia, 37, 40-48. https://doi.org/10.1590/s1413-70542013000100005

Pacheco, R. S., Brito, L. F., Straliotto, R., Perez, D. V., \& Araujo, A. P. (2012). Seeds enriched with phosphorus and molybdenum as a strategy for improving grain yield of common bean crop. Field Crops Research, 136, 97-106. https://doi.org/10.1016/j.fcr.2012.07.017 
Pereira, W. A., Pereira, S. M. A., \& Dias, D. C. F. S. (2015). Dynamics of reserves of soybean seeds during the development of seedlings of different commercial cultivars. Journal of Seed Science, 7, 63-69. http://dx.doi.org/10.1590/2317-1545v37n1142202

Pimentel, M. A., Vasconcellos, M. C., Penha, R. O., Guerra, E. P., \& Silva, A. L. L. (2012). Ação de diferentes enzimas na germinação de sementes de alface (Lactuca sativa L.) Asteraceae. Journal of Biotechnology and Biodiversity, 3, 1-4.

Pujadas, G., \& Palau, J. (2001). Evolution of alpha-amylases: Architectural features and key residues in the stabilization of the $(\beta / \alpha)(8)$ scaffold. Molecular Biology Evolution, 18, 38-54. https://doi.org/10.1093/oxfordjournals.molbev.a003718

Sawan, Z. M., Fahmy, A. H., \& Yousef, S. E. (2011). Effect of potassium, zinc and phosphorus on seed yield, seed viability and seedling vigor of cotton (Gossypium barbadense L.). Archives Agronomy Soil Science, 57, 75-90. https://doi.org/10.1080/03650340903222328

Scheeren, B. R., Peske, S. T., Schuch, L. O. B., \& Barros, A. C. A. (2010). Physiological quality of soybean seeds and productivity. Revista Brasileira de Sementes, 32, 035-041. http://dx.doi.org/10.1590/S0100-83582015000300007

Seyyedi, S. M., Moghaddam, P. R., Khajeh-Hosseini, M., \& Shahandehb, H. (2015). Influence of phosphorus and soil amendments on black seed (Nigella sativa L.) oil yield and nutrient uptake. Industrial Crops and Products, 77, 167-174. https://doi.org/10.1016/j.indcrop.2015.08.065

Shah, H., Jalwat, T., Arif, M., \& Miraj, G. (2012). Seed priming improves early seedling growth and nutrient uptake in mungbean. Journal Plant Nutrition, 35, 805-816. https://doi.org/10.1080/01904167.2012.663436

Siadat, S. A., Moosavi, A., \& Zadeh, M. S. (2012). Effect of seed priming on antioxidant activity and germination characteristics of Maize seeds under different aging treatments. Research Journals of Seed Science, 5, 51-62. https://doi.org/10.3923/rjss.2012.51.62

Simova-Stoilova, L., Demirevska, K., Petrova, T., Tsenov, N., \& Feller, U. (2008). Antioxidative protection in wheat varieties under severe recoverable drought at seedling stage. Plant Soil Environmental, 54, 529-536. https://doi.org/10.7892/boris.30419

Tabaldi, L. A., Cargnelutti, D., Castro, G. Y., Gonçalves, J. F., Rauber, R., Bisognin, D. A., Schetinger, M. R. C., \& Nicoloso, F. T. (2011). Effect of aluminum on the in vitro activity of acid phosphatases of four potato clones grown in three growth systems. Biologia Plantarum, 55, 178-182. https://doi.org/10.1007/s10535-011-0026-6

Tabaldi, L. A., Ruppenthal, R., Carnelutti, D., Morsh, V. M., Pereira, L. B., \& Schetinge, M. R. C. (2007). Effects of metal elements on acid phosphatase activity in cucumber (Cucumis sativus L.) seedlings. Environmental and Experimental Botany, 59, 43-48. https://doi.org/10.1016/j.envexpbot.2005.10.009

Wijewardana, C., Reddy, K. R., \& Bellaloui, N. (2018). Soybean Seed Physiology, quality, and chemical composition under soil moisture stress. Food Chemistry. 
https://doi.org/10.1016/j.foodchem.2018.11.035

Zeraik, A. E., Souza, F. S., \& Fatibello-Filho, O. (2008). Development of a spot test for peroxidase activity monitoring during a purification procedure. Química Nova, 31, 731-734. http://dx.doi.org/10.1590/S0100-40422008000400003

Zhao, M., Zhang, H., Yan, H., Qiu, L., \& Baskin, C. C. (2018). Mobilization and Role of Starch, protein, and fat reserves during seed germination of six wild grassland species. Frontiers in Plant Science, 9, 1-11. https://doi.org/10.3389/fpls.2018.00234

\section{Copyright Disclaimer}

Copyright for this article is retained by the author(s), with first publication rights granted to the journal.

This is an open-access article distributed under the terms and conditions of the Creative Commons Attribution license (http://creativecommons.org/licenses/by/4.0/). 